\title{
Impact of Imported Intermediate and Capital Goods on Economic Growth: A Cross Country Analysis
}

\section{Veeramani}

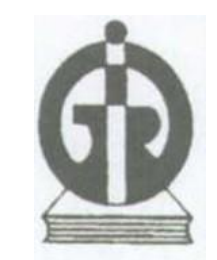

Indira Gandhi Institute of Development Research, Mumbai

December 2008

http://www.igidr.ac.in/pdf/publication/WP-2008-029.pdf 


\title{
Impact of Imported Intermediate and Capital Goods on Economic Growth: A Cross Country Analysis ${ }^{1}$
}

\author{
C. Veeramani \\ Indira Gandhi Institute of Development Research (IGIDR) \\ General Arun Kumar Vaidya Marg \\ Goregaon (E), Mumbai- 400065, INDIA \\ Email (corresponding author): veeramani@igidr.ac.in
}

\begin{abstract}
Knowledge accumulation in the richer countries provides them with comparative advantages in higher productivity products. The countries that import the higher productivity intermediate products and capital equipments produced in the richer countries, however, derive benefits from knowledge spillovers. The empirical analysis in this paper shows that what type of intermediate goods and capital equipments a country imports and from where it imports indeed matters for its long-run growth. Using highly disaggregated trade data for a large number of countries, we construct an index (denoted as IMPY) that measures the productivity level associated with a country's imports. Using instrumental variable method (to address the endogeneity problems), we find that a higher initial value of the IMPY index (for the year 1995) leads to a faster growth rate of income per capita in the subsequent years (during 1995-2005) and vice versa. The results imply that a $10 \%$ increase in IMPY increases growth by about 1.3 tol.9 percentage points, which is quite large.
\end{abstract}

Key words: Imports, Intermediate and Capital Goods, Economic Growth, Productivity JEL Code(s): F10, F43, O40, O47.

\footnotetext{
${ }^{1}$ I thank Sripad Motiram for helpful suggestions. Sushmit Nath provided able research assistance.
} 


\title{
Impact of Imported Intermediate and Capital Goods on Economic Growth: A Cross Country Analysis
}

\author{
C. Veeramani
}

\section{Introduction}

Endogenous growth models emphasize two important mechanisms through which the participation in international trade can raise the long-term growth rate of countries. First, trade enables the use of better (Aghion and Howitt 1992) and larger (Romer 1987) variety of intermediate products and capital equipments ${ }^{2}$. Second, trade plays an important role as a transmission channel for knowledge spillovers across countries (e.g., Grossman and Helpman 1991, Coe and Helpman 1995, Coe et al, 1997, Keller 2000, 2004). Countries that use imported intermediate products and capital equipments derive benefits because these products embody foreign knowledge. Spillovers arise in this process of knowledge diffusion to the extent the imported products cost less than its opportunity costs including the R\&D costs to develop the products. Further, import might facilitate learning about the products (for example, reverse engineering), spurring imitation or innovation of competing products. Also, trade relationships stimulate personal interaction and other channels of communication leading to cross border learning of production methods, product design, organizational methods, and market conditions. Thus, countries import new goods first, then produce them by themselves, and eventually export them (Chuang, 1998).

The extent of trade-induced knowledge spillovers, however, crucially depends upon the tangible and intangible knowledge stock of the trading partners and the learning potential of the traded goods. Acemoglu and Zillibotti (1999) advance a theoretical explanation

\footnotetext{
${ }^{2}$ Empirical analysis by Broda, Greenfield and Weinstein (2006) shows that imported varieties account for $15 \%$ of productivity growth in a typical country in the world, while the effects are larger in the developing countries. See Feenstra (2004) for references to and discussion of the previous studies that show positive correlation between product variety and economic growth.
} 
for the wide variation in knowledge stock across countries. They argue that societies accumulate knowledge by repeating certain tasks and that the scarcity of capital restricts the repetition of various activities. Richer societies, therefore, tend to accumulate more knowledge compared to the poorer societies, which provides the former with a comparative advantage in knowledge-intensive/higher productivity products ${ }^{3}$.

Do the poor countries gain from the knowledge accumulation in the richer countries? Chuang (1998) formulated a trade-induced learning model to show that the poorer countries derive benefits by importing the higher productivity richer country products. More specifically, Chuang's analysis imply that ceteris paribus the greater the share of higher productivity products in the import basket of the country, the higher is the likelihood of trade induced learning and growth. Similarly, Goh and Olivier (2002) establish the positive effect of trade induced learning on the long-term growth rate of the less developed countries. Their model show that access to the capital goods from the developed countries enables a developing country to accumulate capital, which in turn stimulates learning by doing and higher growth ${ }^{4}$.

Recently, a number of empirical analyses have shown that traded goods differ significantly with respect to their implied productivity/ knowledge/ quality levels ${ }^{5}$. For example, Schott (2004) shows that capital and skill-abundant countries use their

\footnotetext{
${ }^{3}$ It may also be noted that an important feature of the general equilibrium trade models developed by Falvey and Kierzkowski (1987), Flam and Helpman (1987), Stockey (1991), and Murphy and Shleifer (1997) is that the rich countries have a comparative advantage in the production of high quality goods. The "Schumpeterian" growth theory propounded by Aghion and Howitt (1992) focuses on quality improving industrial innovations that render old intermediate products obsolete. Thus, if innovations are mainly concentrated in the richer countries, their products are likely to possess higher quality / higher productivity. A central ides of the learning by doing models is that the spectrum of produced goods evolves over time by introducing new and technically sophisticated goods and discarding the old and less sophisticated goods. These models show that the developed country is always one step ahead of the developing country in terms of the technological sophistication of goods produced.

${ }^{4}$ In theories with specialized inputs to production (e.g., Romer, 1987), growth arises from an increase in the number of available varieties of intermediate and capital goods. Trade plays an important role in this framework because a country can grow faster if it is able to import specialized inputs produced abroad. It may be noted that the theme of the present paper is related to the gains from the productivity of varieties rather than from the number of varieties.

${ }^{5}$ Treating the import of a particular good from a particular country as a variety, Broda et al (2006) noted a dramatic increase in the number of imported varieties in the United States between 1972 and 2001. They also noted a similar increase in the number of countries supplying each individual good.
} 
endowment advantage to produce vertically superior product varieties, i.e., varieties that are relatively capital or skill intensive and possess added features or higher quality. Hausman et al (2007) argue that the goods where the richer countries have comparative advantages have higher implied productivity levels compared to the goods where the poorer countries have comparative advantages.

Hausman et al (2007) propose a quantitative index to rank goods in terms of their implied productivity. Their index (denoted as $P R O D Y$ ) is a weighted average of the per-capita GDPs of the countries exporting a product, where the weights are the revealed comparative advantages of each country in that product. Hausman et al (2007) then construct the productivity level that corresponds to a country's export basket (denoted as $E X P Y$ ), by calculating the export-weighted average of the PRODY for that country. Their main hypothesis is that the higher the initial EXPY value of a country, the faster is its subsequent economic growth and vice versa.

The present paper argues that what a country imports and from where it imports matters for its long-run growth. We construct a quantitative index that measures the productivity level associated with a country's import basket. Our measure is closely related to that of Hausman et al (2007), but is quite different in spirit. First, we rank each product in each country with respect to their implied productivity levels using a measure denoted as $P R O D Y_{j k}$. We then construct the productivity level that corresponds to a country's imports of intermediate manufactures and capital goods (denoted as IMPY), by calculating the import-weighted average of the $P R O D Y_{j k}$ for that country. We use highly disaggregated (6-digit) bilateral import data for a large number of countries.

More precisely, we test the hypothesis that the higher the initial IMPY value of a country, the faster is its subsequent economic growth and vice versa. Instrumental variable method is used to address the potential endogeneity problems in the econometric analysis. The results support our hypothesis: we find that controlling for the influence of other variables, a higher (lower) initial value of the IMPY index (for the year 1995) leads 
to a faster (slower) growth rate of income per capita in the subsequent years (during 1995-2005).

The remainder of the paper is structured as follows. The index used to measure the implied productivity level of imports $(I M P Y)$ is explained in Section 2. This section also provides a description of the data set used and presents some descriptive statistics. An econometric analysis of the determinants of $I M P Y$ index is attempted in Section 3. Section 4 deals with the econometric analysis of the impact of IMPY on growth of GDP per capita. Some concluding remarks are given in Section 5. An appendix describes the data sources used for this study.

\section{Measurement, Database and Descriptive Statistics}

\subsection{Measuring the Implied Productivity Level of Imports}

We use data on exports (multilateral flows for each country) and import (bilateral flows for each country) at the 6-digit level covering the whole group of intermediate manufactures and capital goods. The productivity level associated with the 6-digit product $k$ exported from country $j$ is defined as follows.

$$
P R O D Y_{j k}=R C A_{j k} Y_{j}
$$

where $Y_{j}$ is the per-capita real GDP of country $j$ and $R C A_{j k}$ is the revealed comparative advantage of county $j$ in good $k$ defined as $R C A_{j k}=\frac{\left(x_{j k} / X_{j}\right)}{\sum_{j} x_{j k} / \sum_{j} X_{j}}$. The numerator of the $R C A$ index represents the value-share of the good $k$ in the overall export basket of the country $j$. The denominator represents the value-share of $k$ in total world exports ${ }^{6}$. If the $R C A$ value of a product in a country is greater than 1 , it implies that the share of the country's exports in that product is greater than the country's share of exports in all products.

\footnotetext{
${ }^{6}$ This is the well-known Balassa (1965) index of $R C A$.
} 
Hausmann and Rodrik (2003) examine highly disaggregated export data for a large number of countries and conclude that in all countries "industrial success entails concentration in a relatively narrow range of high-productivity activities" (pp 623). Further, Hausmann and Klinger (2006) note that every country tends to have a very specialized basket of exports and that the $R C A$ index captures all its significant exports but leaves aside the noise.

Thus, implicit in the use of $P R O D Y_{j k}$ measure is the idea that for each country, products that record the highest $R C A$ values tend to have the highest productivity levels. Per capita real GDP is taken as a proxy for the knowledge stock of a country. This is consistent with the theory that richer countries accumulate more knowledge (Acemoglu and Zillibotti, 1999). The richer country products with high $R C A$ values are likely to embody higher levels of knowledge / productivity. Therefore, a country stands to gain more if its import basket is biased towards the richer country products, where the latter's $R C A$ values are higher (i.e., products with higher values of $\operatorname{PRODY} Y_{j k}$.).

The productivity level associated with country $i$ 's import basket is defined by.

$$
I M P Y_{i}=\sum_{j} \sum_{k}\left(\frac{m_{i j k}}{M_{i}}\right) P R O D Y_{j k}
$$

This is a weighted average of $P R O D Y_{j k}$ for country $i$, where the weights are the value shares of good $k$ imported from country $j$ in the country's total imports of intermediate manufactures and capital goods. A higher value of $I M P Y_{i}$ implies that country $i$ 's import basket is biased towards the products with higher values of $P R O D Y_{j k}$.

For each country in our sample, the IMPY index is computed for intermediate manufactures and capital goods combined (IMPY $\left.Y_{\text {combined }}\right)$ as well as separately for intermediate manufactures $\left(I M P Y_{\text {inter }}\right)$ and capital goods $\left(I M P Y_{\text {capital }}\right)$. It is important to distinguish between capital goods and non-capital goods because the former may have higher content of knowledge than the latter (Xu and Wang, 1999). 


\subsection{Data and Methods}

Trade data at the 6-digit level of Harmonized System (HS) comes from the United Nations COMTRADE database accessed through the World Integrated Trade Statistics (WITS) software. The value of exports and imports is measured in current US dollars. The WITS software provides a concordance between 6-digit HS codes and the classification of international trade by Broad Economic Categories (BEC) by the United Nations (UN) Secretariat. We use this concordance table to identify the products belonging to the group of intermediate manufactures and capital goods ${ }^{7}$.

Even though trade data according to the HS system is available since 1992, the number of reporting countries varies considerably from year to year ${ }^{8}$. The number of countries reporting the export data (which is required to compute the RCA) was only 55 in 1992, which was increased to 114 in 1995 and to 161 in 2000. The number of countries reporting data for the most recent years is considerably less (133 in 2005 and 71 in 2006) due to the time lag in reporting the data. Hausman et al (2007) pointed out that nonreporting of trade data is likely to be correlated with income, and therefore using data for different countries and different years could introduce serious bias into the PRODY index. They note that it is therefore important to use data for a consistent sample of countries. We noticed that 148 countries have consistently reported the export data in each of the years 2001-2003 ${ }^{9}$. While export data was available for a consistent sample of 148 countries, real per capita income data for the year 1995 was available in the World Development Indicators (WDI) database for 133 of these countries.

\footnotetext{
${ }^{7}$ The 6-digit HS codes corresponding to the following BEC codes have been used for the analysis: processed industrial supplies not elsewhere specified (BEC 22); capital goods, except transport equipments (BEC 41); parts and accessories of capital goods, except transport equipments (BEC 42); parts and accessories of transport equipments (BEC 53); other processed fuels and lubricants (BEC 322); and industrial transport equipments (BEC 521). Following the UN classification, BEC 41 and BEC 521 constitute the group of "capital goods" while the rest of the BEC codes are "intermediate manufactures". Excluded from our analysis are petroleum products (HS 27), processed food and beverages (BEC 121), various primary intermediate products and various final consumer products.

${ }^{8}$ Data according to SITC is available for a longer period but at a more aggregate level. However, it is appropriate to use more disaggregated data for the purpose in hand. Therefore, we prefer data according to the HS classification.

${ }^{9}$ This is the maximum number of countries that have consistently reported export data for a reasonable number of years.
} 
Therefore, $P R O D Y_{j k}$ is computed for 133 countries using the real per capita income (both PPP-adjusted and at market exchange rates) of the countries in the year 1995 and the average value of $R C A_{j k}$ for the period 2001-2003 ${ }^{10}$. Use of the average value of $R C A_{j k}$ for a period, rather than the value for just one year, is consistent with the evidence provided by Besedes and Prusa (2006) on the duration of exports at the product level. They observe that if a country is able to survive in the exporting market for the first few years, the probability of it exporting the product for a long period of time is very high. They further note that the technologically advanced countries tend to have longer duration of export. Thus, a consistently high $R C A$ in a product over a period of time would indicate the "true" (rather than transitory) comparative advantage of the country in that product.

Computation of IMPY requires bilateral import data. While import data at the 6-digit level of HS for the year 1995 were available for 113 countries $^{11}$, we exclude the small countries with population less than 1 million in $1995^{12}$. The real per capita GDP for the period 1995-2005 was available for 90 countries (with population more than 1 million) for which bilateral import data were also available.

\subsection{Descriptive Statistics}

As expected, richer countries generally record higher $P R O D Y_{j k}$ values compared to poorer countries. This is evident from Figure 1, which is a scatter plot between the per capita incomes and the average $P R O D Y_{j k}$ values of countries (the correlation coefficient is 0.81 ). However, in a significant number of products where their $R C A$ values are

\footnotetext{
${ }^{10}$ We do not compute the $R C A$ index for the year 1995 as the number of countries reporting the export data in that year is considerably less (114) which can introduce some serious bias into the $I M P Y i$ index. Not using the $1995 R C A$ is not serious problem as studies show a very high correlation of the individual country's $R C A$ values over the years. Following similar considerations, Hausman et al (2007) computed the $R C A$ values for the period 1999-2001, where trade data were available consistently for 124 countries. We have selected the period 2001-2003 since trade data was available consistently for a larger number of countries (148) for this period.

${ }^{11}$ The number of countries reporting import data for the year 1994 is only 96 . For Belgium and Luxemburg, import data was not available separately for the year 1995, and thus, we computed the IMPY index (as well as $P R O D Y_{j k}$ ) for Belgium and Luxemburg combined.

${ }^{12}$ The excluded countries are: St. Kitts and Nevis, Dominica, Seychelles, Kiribati, Grenada, St. Vincent and Grenadines, St. Lucia, Belize, Iceland, Malta, Macao, Suriname, Comoros and Cyprus. It may be noted that all these are island nations except Belize, Suriname, Comoros and Cyprus.
} 
higher, many poor countries show high $P R O D Y_{j k}$ values. This is evident from Table 1, where we consider the distribution of 1000 largest $P R O D Y_{j k}$ values (out of the total 2,45,202 $P R O D Y_{j k}$ values across all countries and products). It may be noted that 16 $P R O D Y_{j k}$ values in this list pertains to the poorest countries of the world (i.e. countries with GDP per capita less than $\$ 1000$ in PPP terms). These high values of the poorest countries are mostly in natural resource intensive manufactures ${ }^{13}$. Further, as many as 55 $P R O D Y_{j k}$ values in the list pertains to the countries with GDP per capita (PPP) less than $\$$ 2000 and 209 values pertains to the countries with GDP per capita (PPP) less than $\$ 5000$. Thus, the poorer countries indeed show high $P R O D Y_{j k}$ values in some products where their $R C A$ values are very high. We also notice that products that record high $P R O D Y_{j k}$ values in the poorer countries have little presence in the export basket of richer countries.

Figure 2 shows the scatter plot of IMPY against per-capita GDP. As expected, these two variables are positively correlated (the correlation coefficient is 0.68). The positive correlation indicates that rich (poor) countries generally tend to import goods with higher (lower) $P R O D Y_{j k}$ values. The one outlier on the lower left hand side of the scatter plot is Kyrgyz Republic (KGZ), a land locked and a predominantly agricultural economy. The low IMPY value of $\mathrm{KGZ}$ relative to its per capita income is related to the fact that just three middle-income countries (Russia, Turkey and Kazakhstan) account for as high as $71 \%$ of its imports of intermediate manufactures and capital goods.

Table 2 provides the lists of the 25 countries with the largest values of IMPY (Group 1) and the 25 countries with the smallest values of $I M P Y$ (Group 2). It may be of interest to note that countries in Group 1 include some of the fastest growing economies of the world such as China, India, Latvia and Ireland. In general, the average annual growth rates of per capita income (during 1995-2005) of the countries in Group 1 are higher than those in Group 2. While as many as 8 countries in Group 2 (Burundi, Central African Rep., Madagascar, Niger, Paraguay, Togo, Uruguay, Zimbabwe) showed a negative

\footnotetext{
${ }^{13}$ For example Ethiopia shows high $P R O D Y_{j k}$ in various leather products (HS codes: 410421, 410619, 410519, 410611, 410511) and in Cotton carded or combed (HS 520300) and Zambia in articles made of Combalt (HS codes 810510, 810590). Though the per capita incomes of these two countries are among the lowest in the world (\$739 for Ethiopia and $\$ 766$ for Zambia in PPP terms), the high PRODY $Y_{j k}$ values of these countries in these products are due to their high $R C A$ values.
} 
average annual growth rate of per capita income during 1995-2005, only 1 country in Group 1 (Venezuela) showed a negative growth rate.

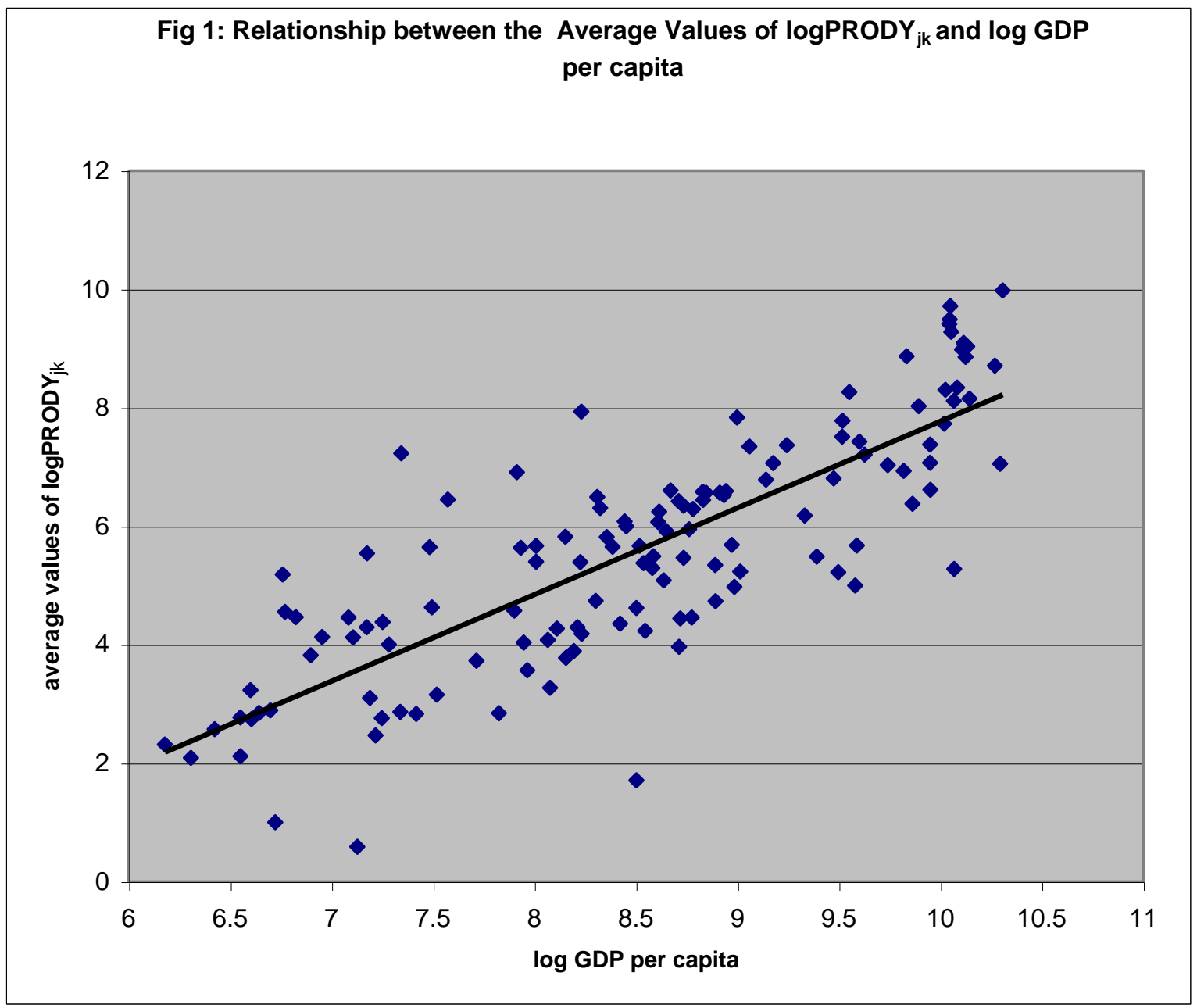

Table 1: Relationship between GDP per capita and $P R O D Y_{j k}$ Values (Distribution of the 1000 Largest $P R O D Y_{j k}$ Values)

\begin{tabular}{|l|c|}
\hline GDP per capita (PPP) of Countries & $\begin{array}{l}\text { Number of Products in the Group of } 1000 \\
\text { Largest PROD } Y_{j k} \text { Values }\end{array}$ \\
\hline less than $\$ 1000$ & 16 \\
\hline less than $\$ 2000$ & 55 \\
\hline less than $\$ 5000$ & 209 \\
\hline less than $\$ 10,000$ & 433 \\
\hline greater than $\$ 10,000$ & 567 \\
\hline
\end{tabular}




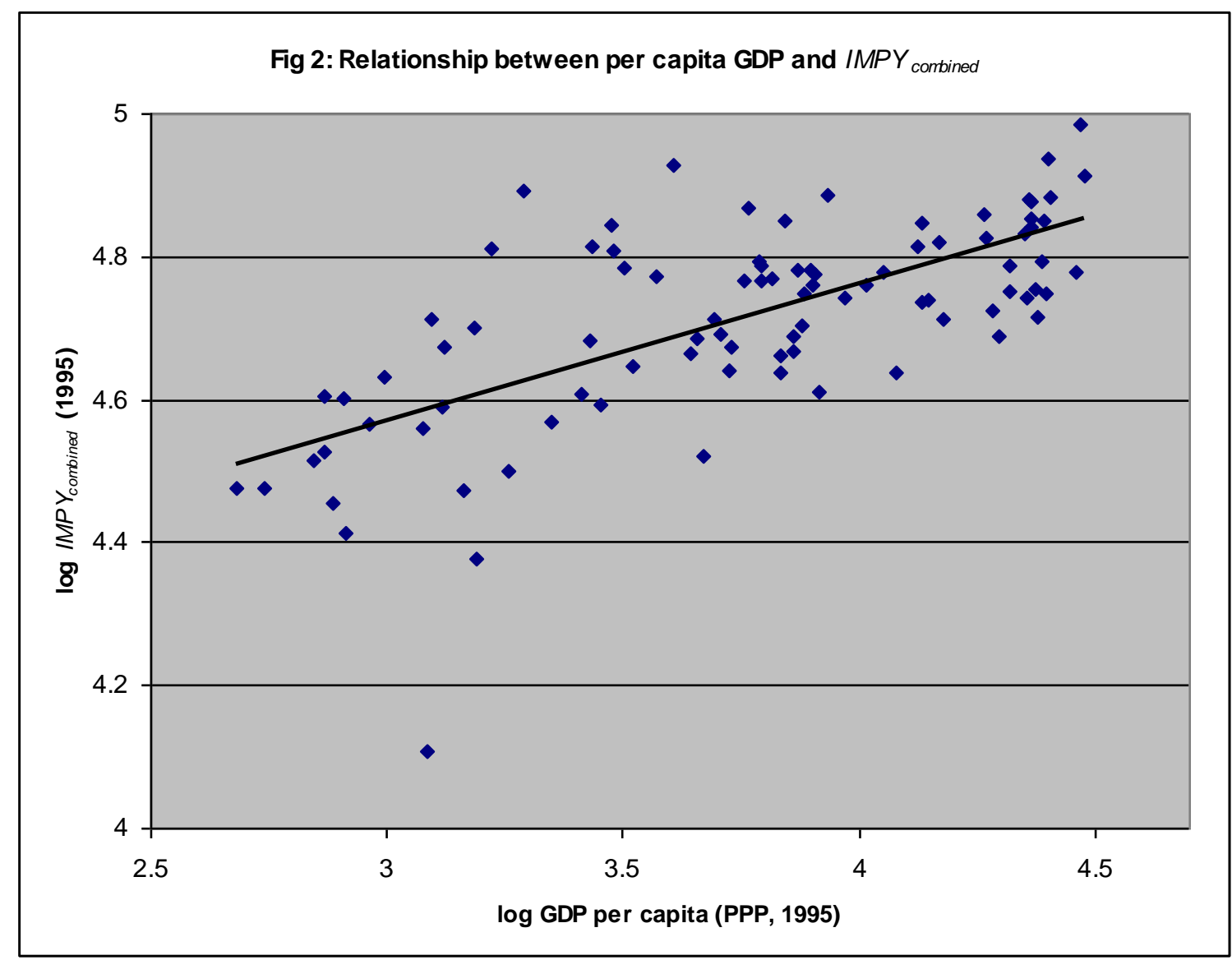

Further, countries in Group 1 are generally larger in size compared to those in Group 2. It may also be noted that while as many as 14 countries in Group 2 are landlocked, no country in Group 1 is landlocked. Thus, it appears that geographical characteristics of the countries exert influence on the levels of IMPY. Below we argue that certain geographical characteristics of countries can be used to obtain the instrumental variables estimates of IMPY's impact on growth.

It may be noted that Group 2 includes four countries belonging to the former Soviet Union (FSU), while Group 1 includes only one FSU country (Latvia). Two of the FSU countries in Group 2 (Lithuania and Estonia) are among the fastest growing economies of the world, while the growth rates of the remaining two (Kyrgyz Rep and Moldova) are higher than that of most countries in Group 2. 
Table 2: Largest and Smallest IMPY values

\begin{tabular}{|c|c|c|c|c|c|c|c|}
\hline \multicolumn{4}{|c|}{ Group 1: Largest $I M P Y$ values } & \multicolumn{4}{|c|}{ Group 2: Smallest $I M P Y$ values } \\
\hline \multicolumn{2}{|c|}{$I M P Y_{\text {inter }}$} & \multicolumn{2}{|c|}{$I M P Y_{\text {capital }}$} & \multicolumn{2}{|c|}{$I M P Y_{\text {inter }}$} & \multicolumn{2}{|c|}{$I M P Y_{\text {capital }}$} \\
\hline Countries & Value & Countries & Value & Countries & Value & Countries & Value \\
\hline Norway & 110659 & Latvia & 76926 & Kyrgyz Rep & 10146 & Kyrgyz Rep & 17960 \\
\hline Jordan & 98702 & Ireland & 69577 & Chad & 24065 & Malawi & 23065 \\
\hline $\begin{array}{l}\text { Japan } \\
\text { South }\end{array}$ & 96053 & Turkey & 69385 & Gambia & 24231 & Gambia & 23271 \\
\hline Africa & 89136 & USA & 68610 & Zambia & 27371 & Tanzania & 26308 \\
\hline USA & 87472 & Korea Rep. & 65946 & $\begin{array}{l}\text { Moldova } \\
\text { Central }\end{array}$ & 28630 & Chad & 30200 \\
\hline Denmark & 85860 & Norway & 64540 & African Rep & 31082 & Zambia & 30224 \\
\hline $\begin{array}{l}\text { India } \\
\text { New }\end{array}$ & 83467 & Romania & 62067 & Guinea & 31100 & Sudan & 30973 \\
\hline Zealand & 82369 & Thailand & 61607 & Tanzania & 31430 & Burkina Faso & 31272 \\
\hline France & 82067 & Germany & 60703 & Burundi & 31699 & Uruguay & 33202 \\
\hline Brazil & 80020 & Israel & 58716 & Niger & 32008 & Moldova & 33965 \\
\hline Germany & 80019 & India & 58611 & Paraguay & 32067 & Guinea & 33978 \\
\hline Turkey & 76219 & Slovenia & 58331 & Malawi & 33263 & Paraguay & 34502 \\
\hline Italy & 75799 & China & 58101 & Togo & 37525 & Bangladesh & 34638 \\
\hline Australia & 75363 & Malaysia & 57511 & Burkina Faso & 38436 & Bolivia & 34854 \\
\hline $\begin{array}{l}\text { Belgium- } \\
\text { Luxemburg }\end{array}$ & 75104 & $\begin{array}{l}\text { Greece } \\
\text { South }\end{array}$ & 57355 & Madagascar & 38665 & Zimbabwe & 35211 \\
\hline U.K & 74975 & Africa & 57318 & Bolivia & 38685 & Ethiopia & 35392 \\
\hline $\begin{array}{l}\text { Indonesia } \\
\text { Saudi }\end{array}$ & 74955 & France & 57297 & Honduras & 38916 & Niger & 35709 \\
\hline Arabia & 73077 & Spain & 57010 & Oman & 42561 & Ecuador & 36182 \\
\hline Korea Rep & 72431 & Indonesia & 56815 & Uganda & 42992 & Peru & 36886 \\
\hline Venezuela & 70762 & Poland & 56813 & Lithuania & 43490 & Algeria & 39284 \\
\hline Cameroon & 70700 & $\begin{array}{l}\text { Japan } \\
\text { New }\end{array}$ & 56495 & Ethiopia & 43730 & Honduras & 39623 \\
\hline Spain & 70072 & Zealand & 56135 & Panama & 44089 & Burundi & 39813 \\
\hline Egypt & 69353 & Australia & 56078 & Zimbabwe & 44430 & Saudi Arabia & 39901 \\
\hline China & 69161 & Italy & 56078 & Uruguay & 44515 & $\begin{array}{l}\text { El Salvador } \\
\text { Central }\end{array}$ & 39923 \\
\hline Greece & 68848 & Tunisia & 56000 & Estonia & 46242 & African Rep & 40105 \\
\hline
\end{tabular}

Studies suggest that the FSU countries exhibit a very strong "home bias" in the direction of trade both before and after the disintegration in comparison with what is typically found in the literature (Fidrmuc and Fidrmuc, 2003). The high intensity of "inter- 
republican trade" might lower the values of their $I M P Y^{14}$. It may, however, be noted that despite their relatively lower IMPY values, the FSU countries have experienced significant growth rate of output since the second half of the 1990s subsequent to the initial contraction during the first half of the 1990s (Iradian, 2007). In particular, the Baltic States (Estonia, Latvia, Lithuania) have undergone rapid economic expansion. The faster economic growth of the FSU countries, despite their relatively small initial IMPY values, may suggest that it is appropriate to include the FSU Dummy in the growth regressions.

\section{Determinants of IMPY}

In order to understand the factors that determine the cross-country variation of IMPY, we draw upon the insights of the gravity models of trade and some recent studies that have emphasized the importance of commercial networks in promoting international trade ${ }^{15}$. Commercial networks promote trade by alleviating problems of contract enforcement, by reducing the search costs of trade and by providing information about trading opportunities. Rauch (1996) observed that international exchange of manufactured products does not occur in organized markets like those of primary commodities. For manufactured products differ too much in their quality and characteristics for quoted prices to reveal all the information required by traders to finalize their operations. Hence the connection between the sellers and buyers is often the result of a costly and lengthy search process, which is "strongly conditioned by proximity and preexisting ties and results in trading networks rather than markets" (Rauch, 1999, pp 8). The transaction and search costs of international trade will vary across countries depending upon a country's chance and ability to create 'trading networks' across the world and its geographical proximity with the potential suppliers ${ }^{16}$.

\footnotetext{
14 The "home bias" implies that these countries in general may fail to import the products from the best sources (i.e., from the countries with the highest $P R O D Y_{j k}$ values). Let us also note that most of the FSU countries belong to the groups of low and lower middle-income countries and none of them belong to the group of high-income countries. Both these observations imply that the import basket of the former Soviet Union countries would be biased towards the products with relatively lower values of $P R O D Y_{j k}$. This, in turn, leads to their lower $I M P Y$ values.

${ }^{15}$ See Rauch (2001) for a survey of the studies on trading networks.

${ }^{16}$ Geographical proximity is found to stimulate international technological diffusion as well (Keller, 2004).
} 
That the volume of bilateral trade falls with geographical distance is a well documented fact (e.g., Leamer and Levinsohn, 1995). The volumes of bilateral trade between geographically closer countries tend to be higher due to the lower search costs and other advantages arising from greater geographical proximity. We consider a variable defined as the sum of geographical distances between a given country and each of the highincome OECD countries, weighted by the latter's GDP. Given that the richer countries, on an average, have higher $P R O D Y_{j k}$ values compared to the poorer countries, we expect that the farther a country is located from the high-income countries, the lower will be the value of its IMPY. The logarithm of this variable (log distance) shows a large statistically significant negative coefficient (Table 3). The value of the coefficient indicates that a $10 \%$ increase in the distance from the high-income countries would reduce the IMPY value of a country by about 1.1 to 1.5 percentage points.

The gravity models of trade generally show that the landlocked status of the partner countries reduces the volume of bilateral trade. This is related to the fact that landlocked countries suffer from high transaction and search costs of international trade due to their lack of direct access to the sea. Thus, landlocked countries depend heavily on their neighbors for both exports and imports. The relatively high transaction and search costs of international trade in the landlocked countries may adversely affect their chance of importing the products from the "best" sources, that is, from the countries with the highest $P R O D Y_{j k}$ values. Therefore, we expect that the $I M P Y$ values of the landlocked countries are likely to be smaller. Indeed, the dummy for landlocked countries $(=1$ for landlocked countries and 0 otherwise) shows a statistically significant negative coefficient in Table 3.

The transaction and search costs of the island nations, however, are potentially lower due to their access to sea. In particular, their trade routes with the developed world could be relatively well developed. In general, the island nations might be better positioned to import products from the "best" sources. Indeed, the island dummy (= 1 for island countries and 0 otherwise) shows a significant positive coefficient in Table 3. 
Finally, we consider size (proxied by population) of the importing country. Higher population may imply larger number of people being engaged in the search process across the world leading to better information flows on trading opportunities. As expected, population enters the IMPY equation with a statistically significant positive coefficient.

All of the above variables (distance, landlocked dummy, island dummy, and country size) are related to the geographic characteristics of the countries. These variables are not affected by the economic growth rates or by the factors (other than trade) that influence economic growth rates (Frankel and Romer, 1999). Thus, countries' geographic characteristics can be used to obtain instrumental variables estimates of IMPY's impact on growth ${ }^{17}$.

The results in Table 3 suggest that per capita income continue to be an important determinant of $I M P Y$ even when all other covariates are included. Human capital (proxied by secondary school enrollment ratio) and rule of law index yield statistically insignificant coefficients suggesting that $I M P Y$ is not a proxy for the human capital endowment or the institutional quality of a country. Though trade/GDP ratio is significantly negative in specification (4), it looses statistical significance in specification (5) where population is included. This result could be related to the well-known regularity that small countries have higher shares of trade in GDP (Rose, 2006) ${ }^{18}$. Finally, as expected, the FSU Dummy ( $=1$ for the FSU countries) shows a negative coefficient reflecting the relatively low IMPY values of the FSU countries due to their high "home bias" in trade.

\footnotetext{
${ }^{17}$ Rose (2006) noted that country's population has no significant impact on economic growth. Thus, using population as an instrument does not pose much problem (see also Frankel and Romer, 1999; and Hausmann et al, 2007).

${ }^{18}$ The correlation between the logarithms of population and trade/GDP ratio in our data is significantly negative (-0.56).
} 
Table 3: Determinants of IMPY (Dependent Variable: $\log I M P Y$, PPP, 1995)

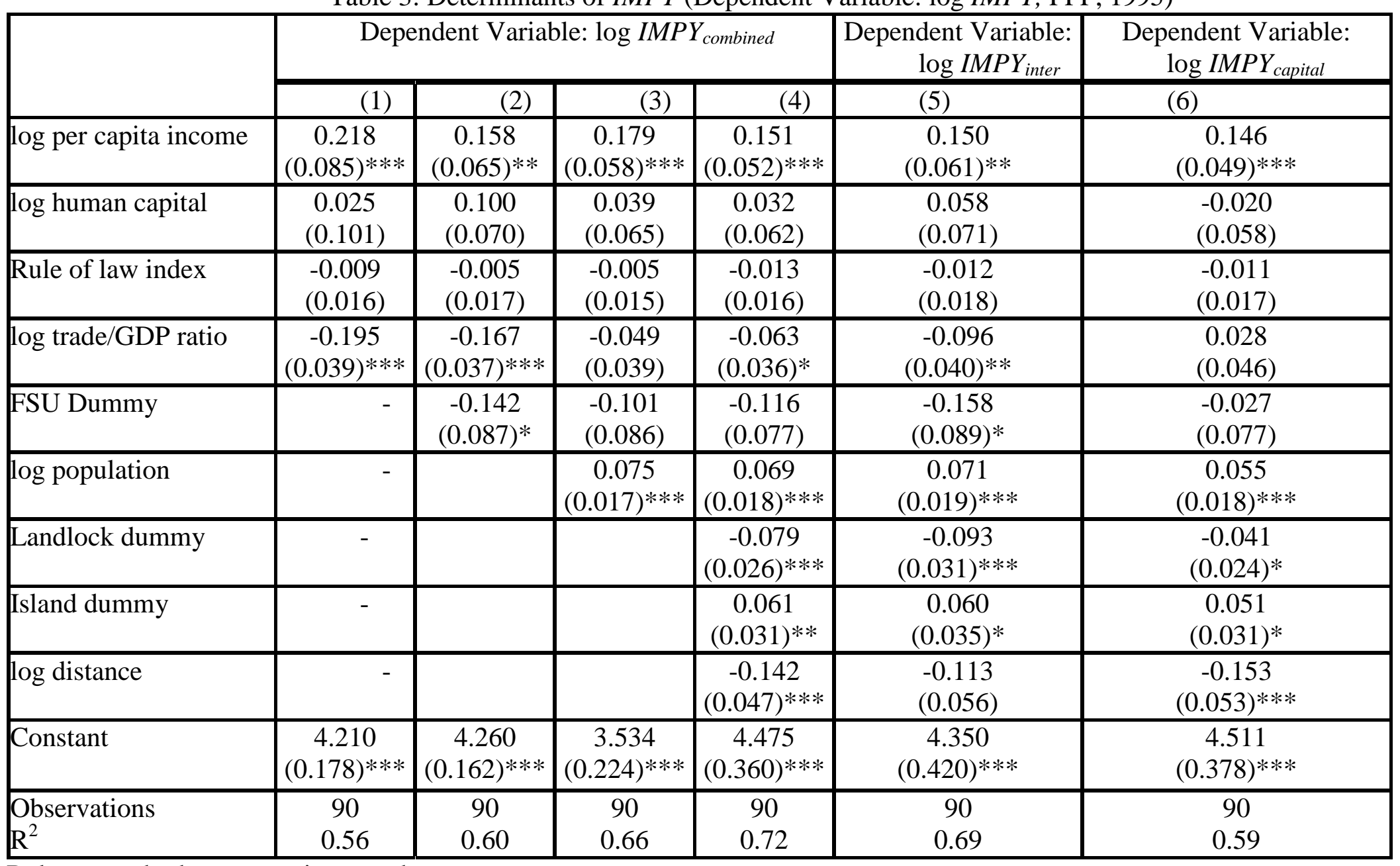

Robust standard errors are in parentheses.

* Significant at $10 \%$ level; ** Significant at 5\% level; *** Significant at $1 \%$ level. 


\section{IMPY and Growth}

We now turn to discuss the cross-country regressions in which the average growth rate of per capita income during 1995-2005 is regressed on initial values of IMPY and other regressors. All the specifications include initial per-capita GDP as a control variable. We also include secondary school enrollment ratio and rule of law index to control for the effects of human capital and institutional quality respectively. Trade/GDP ratio is included to capture the effect of trade openness on growth. All these are standard variables in growth regressions ${ }^{19}$.

Results of the Ordinary Least Squares (OLS) estimations are shown in Table 4. Column (1) reports the results from the growth regression on variables excluding IMPY. All these variables show statistically and economically significant effects on growth. The results confirm that the countries with low initial per capita income levels grow faster, thus supporting the conditional convergence hypothesis. Human capital variable yields positive coefficient, but looses statistical significance if FSU Dummy is added to the equation. As expected, rule of law index and trade/GDP ratio show statistically significant positive coefficients, underscoring the positive effects of institutional quality and trade openness on growth.

Columns (2) through (7) in Table 4 report the regression results after adding the log of initial $I M P Y$ values to the basic equation. As expected, the different $I M P Y$ indices yield positive coefficients. It may, however, be noted that $I M P Y_{\text {combined }}$ and IMPY inter are statistically significant only if the FSU Dummy is added to the equation. However, $I M P Y_{\text {capital }}$ shows a statistically significant positive coefficient even if the FSU Dummy is not included. The estimated coefficient varies from 0.034 to 0.071 , with the coefficient of IMPY $Y_{\text {capital }}$ being larger than that of IMPY $Y_{\text {inter. }}$

\footnotetext{
19 Apart from these variables commonly used in many studies, there are many other factors that may affect growth. But, there is no reason to expect those additional independent variables to be correlated with our instruments. Therefore, the effect of other variables can be included in the error term (Frankel and Romer, 1999).
} 
The FSU Dummy shows a statistically significant positive coefficient in all specifications. It may also be noted that inclusion of the FSU Dummy leads to a significant increase of the point estimates and $t$ values of IMPY and the overall goodness fit of the regressions. As already mentioned, it is important to add the FSU Dummy in our growth regression considering the faster growth of the FSU countries since the second half of the 1990s despite their relatively small initial IMPY values.

Though the IMPY indices show the expected positive coefficient in the OLS regression, a major econometric concern, however, is that this variable is potentially endogenous leading to biased estimates. It is likely that $I M P Y$ is correlated with omitted variables that are relevant to growth. The method of instrumental variables (IV) can be used to address the problem of endogeneity. However, if IMPY is actually exogenous, the OLS method should be used since the IV estimator will be less efficient than OLS when the explanatory variables are exogenous (Wooldridge, 2003). Therefore, in order to decide whether IV estimation is needed, it is important to have a test for the endogeneity of IMPY.

Following Wooldrige (2003), we first obtain the residuals corresponding to the first stage regression equations (4) (5) and (6) in Table 3. We then re-estimate the OLS growth regressions after including these first stage residuals as explanatory variables. As evident from Table 5, the coefficients of these residuals show a statistically significant coefficient, confirming that IMPY is indeed endogenous. The hypothesis that the IV and OLS estimates are equal is rejected at the $5 \%$ level in the case of IMPYcombined and $I M P Y_{\text {inter }}$ and at the $1 \%$ level in the case of $I M P Y_{\text {capital. }}$ 
Table 4: Cross-Country Growth Regressions, OLS Estimation

(Dependant Variable: growth rate of GDP per capita (PPP) over 1995-2005)

\begin{tabular}{|c|c|c|c|c|c|c|c|}
\hline & $(1)$ & (2) & (3) & (4) & $(5)$ & (6) & (7) \\
\hline log initial per capita income & $\begin{array}{l}-0.034 \\
(0.009) * * *\end{array}$ & $\begin{array}{l}-0.040 \\
(0.011)^{* * *}\end{array}$ & $\begin{array}{l}-0.031 \\
(0.011)^{* * * *}\end{array}$ & $\begin{array}{l}-0.038 \\
(0.011)^{* * *}\end{array}$ & $\begin{array}{l}-0.029 \\
(0.011)^{* * *}\end{array}$ & $\begin{array}{l}-0.045 \\
(0.010)^{* * *}\end{array}$ & $\begin{array}{l}-0.034 \\
(0.010)^{* * *}\end{array}$ \\
\hline log human capital & $\begin{array}{l}0.036 \\
(0.011) * * *\end{array}$ & $\begin{array}{l}0.035 \\
(0.011)^{* * *}\end{array}$ & $\begin{array}{l}0.017 \\
(0.012)\end{array}$ & $\begin{array}{l}0.036 \\
(0.011)^{* * * *}\end{array}$ & $\begin{array}{l}0.018 \\
(0.012)\end{array}$ & $\begin{array}{l}0.035 \\
(0.011)^{* * *}\end{array}$ & $\begin{array}{l}0.020 \\
(0.012)^{*}\end{array}$ \\
\hline Rule of law index & $\begin{array}{l}0.010 \\
(0.004) * * *\end{array}$ & $\begin{array}{l}0.011 \\
(0.004)^{* * * *}\end{array}$ & $\begin{array}{l}0.010 \\
(0.003) * * *\end{array}$ & $\begin{array}{l}0.011 \\
(0.004) * * *\end{array}$ & $\begin{array}{l}0.010 \\
(0.003) * * *\end{array}$ & $\begin{array}{l}0.011 \\
(0.004) * * *\end{array}$ & $\begin{array}{l}0.010 \\
(0.003) * * *\end{array}$ \\
\hline log trade/GDP & $\begin{array}{l}0.012 \\
(0.007)^{*}\end{array}$ & $\begin{array}{l}0.017 \\
(0.007)^{* *}\end{array}$ & $\begin{array}{l}0.015 \\
(0.006) * *\end{array}$ & $\begin{array}{l}0.015 \\
(0.007) * *\end{array}$ & $\begin{array}{l}0.014 \\
(0.006)^{* *}\end{array}$ & $\begin{array}{l}0.016 \\
(0.007)^{* *}\end{array}$ & $\begin{array}{l}0.010 \\
(0.006) *\end{array}$ \\
\hline $\log$ initial $I M P Y_{\text {combined }}$ & - & $\begin{array}{l}0.027 \\
(0.019) \\
\end{array}$ & $\begin{array}{l}0.048 \\
(0.019) * * *\end{array}$ & - & - & - & - \\
\hline $\log$ initial $I M P Y_{\text {inter }}$ & - & - & - & $\begin{array}{l}0.014 \\
(0.015)\end{array}$ & $\begin{array}{l}\mathbf{0 . 0 3 4} \\
(0.016) * *\end{array}$ & - & - \\
\hline $\log$ initial $I M P Y_{\text {capital }}$ & - & - & - & - & - & $\begin{array}{l}\mathbf{0 . 0 6 5} \\
(0.025)^{* * *}\end{array}$ & $\begin{array}{l}\mathbf{0 . 0 7 1} \\
(\mathbf{0 . 0 2 1})^{* * * *}\end{array}$ \\
\hline FSU Dummy & - & - & $\begin{array}{l}0.033 \\
(0.009) * * *\end{array}$ & - & $\begin{array}{l}0.033 \\
(0.010) * * *\end{array}$ & - & $\begin{array}{l}0.029 \\
(0.008) * * *\end{array}$ \\
\hline Constant & $\begin{array}{l}0.063 \\
(0.030)^{* *}\end{array}$ & $\begin{array}{l}-0.053 \\
(0.080)\end{array}$ & $\begin{array}{l}-0.151 \\
(0.076) * *\end{array}$ & $\begin{array}{l}0.004 \\
(0.065)\end{array}$ & $\begin{array}{l}-0.092 \\
(0.069)\end{array}$ & $\begin{array}{l}-0.207 \\
(0.105)^{* *}\end{array}$ & $\begin{array}{l}-0.243 \\
(-2.96) * * *\end{array}$ \\
\hline $\begin{array}{l}\text { Observations } \\
\mathrm{R}^{2}\end{array}$ & $\begin{array}{l}90 \\
0.25\end{array}$ & $\begin{array}{l}90 \\
0.27\end{array}$ & $\begin{array}{l}90 \\
0.37\end{array}$ & $\begin{array}{l}90 \\
0.26\end{array}$ & $\begin{array}{l}90 \\
0.35\end{array}$ & $\begin{array}{l}90 \\
0.32\end{array}$ & $\begin{array}{l}90 \\
0.40\end{array}$ \\
\hline
\end{tabular}

Robust standard errors are in parentheses.

* Significant at $10 \%$ level; ** Significant at 5\% level; *** Significant at $1 \%$ level 
Table 5: Testing for the Endogeneity of IMPY (Dependent Variable: log IMPY, PPP, 1995)

\begin{tabular}{|c|c|c|c|}
\hline & $(1)$ & (2) & (3) \\
\hline log initial per capita income & $\begin{array}{l}-0.043 \\
(0.012) * * *\end{array}$ & $\begin{array}{l}-0.042 \\
(0.012)^{* * *}\end{array}$ & $\begin{array}{l}-0.048 \\
(0.013) * * *\end{array}$ \\
\hline log human capital & $\begin{array}{l}0.009 \\
(0.010)\end{array}$ & $\begin{array}{l}0.007 \\
(0.011)\end{array}$ & $\begin{array}{l}0.017 \\
(0.010) *\end{array}$ \\
\hline Rule of law index & $\begin{array}{l}0.011 \\
(0.003) * * *\end{array}$ & $\begin{array}{l}0.011 \\
(0.003) * * *\end{array}$ & $\begin{array}{l}0.010 \\
(0.003) * * *\end{array}$ \\
\hline log trade/GDP & $\begin{array}{l}0.028 \\
(0.008) * * *\end{array}$ & $\begin{array}{l}0.031 \\
(0.009) * * *\end{array}$ & $\begin{array}{l}0.015 \\
(0.006) * *\end{array}$ \\
\hline FSU Dummy & $\begin{array}{l}0.044 \\
(0.010) * * *\end{array}$ & $\begin{array}{l}0.048 \\
(0.011)^{* * *}\end{array}$ & $\begin{array}{l}0.032 \\
(0.008) * * *\end{array}$ \\
\hline $\log$ initial $I M P Y_{\text {combined }}$ & $\begin{array}{l}0.128 \\
(0.040) * * *\end{array}$ & - & \\
\hline $\log$ initial $I M P Y_{\text {inter }}$ & - & $\begin{array}{l}0.114 \\
(0.038) * * *\end{array}$ & \\
\hline $\log$ initial $I M P Y_{\text {capital }}$ & - & - & $\begin{array}{l}0.173 \\
(0.049) * * *\end{array}$ \\
\hline Residual (IMPY $\left.Y_{\text {combined }}\right)$ & $\begin{array}{l}-0.113 \\
(0.044)^{* *}\end{array}$ & - & \\
\hline Residual $\left(I M P Y_{\text {inter }}\right)$ & - & $\begin{array}{l}-\mathbf{0 . 1 0 8} \\
(0.043)^{* *}\end{array}$ & \\
\hline Residual $\left(I M P Y_{\text {capital }}\right)$ & - & - & $\begin{array}{l}\mathbf{- 0 . 1 2 7} \\
(0.049) * * *\end{array}$ \\
\hline Constant & $\begin{array}{l}-0.490 \\
(0.159) * * *\end{array}$ & $\begin{array}{l}-0.436 \\
(0.155)^{* * *}\end{array}$ & $\begin{array}{l}-0.664 \\
(0.191)^{* * * *}\end{array}$ \\
\hline $\begin{array}{l}\text { Observations } \\
\mathrm{R}^{2}\end{array}$ & $\begin{array}{l}90 \\
0.42\end{array}$ & $\begin{array}{l}90 \\
0.41\end{array}$ & $\begin{array}{l}90 \\
0.45\end{array}$ \\
\hline
\end{tabular}

Robust standard errors are in parentheses.

* Significant at $10 \%$ level; ** Significant at 5\% level; *** Significant at $1 \%$ level

Table 6 reports the IV estimates of the impact of IMPY on growth. The first-stage Fstatistics on excluded instruments are large enough that the finite-sample bias of IV estimates that arise from weak instruments is unlikely to be a problem in our IV regressions. It is clear that all the $I M P Y$ indices enter the growth regression with large positive and statistically significant coefficients. It is clear that the OLS underestimates the impact of IMPY. The estimated coefficient from IV regressions varies from 0.078 to 0.173, with the coefficient of $I M P Y_{\text {capital }}$ being larger than that of IMPY $Y_{\text {inter }}$. Taking the midpoint of this range, the results imply that a $10 \%$ increase in IMPY increases growth by 
1.3 percentage points, which is quite large. The higher coefficient value of $I M P Y_{\text {capital }}$ is expected as capital goods have higher content of knowledge than the non-capital goods. It may also be noted that inclusion of the FSU Dummy always leads to an increase of the coefficient values and t-statistics of the IMPY indices. Other variables continue to show statistically and economically significant coefficients: the point estimates of initial per capita income and trade/GDP ratio are larger in the IV regressions compared to the OLS.

Before concluding the paper, we conduct some additional sensitivity analysis. First, though, there exists no evidence that countries with higher population grows faster (Rose, 2006, p.15), many endogenous growth theories contain scale effects. Thus, the excludability of country size from the second stage regression may be questioned on theoretical grounds. Therefore, we re-estimate the IV regressions after dropping country size (log population) from the list of instrumental variables (Table 7). It is clear that dropping of country size in fact strengthens our findings in that the point estimates of $I M P Y$ are now much larger varying from 0.112 to 0.261 . This implies that a $10 \%$ increase in $I M P Y$ increases growth by 1.9 percentage points.

Second, we might expect to see a stronger effect of IMPY for sample that include only the developing countries. The results for the developing country sample are shown in Table 8 (here, country size is included as an instrument). However, we find little evidence that the effect of IMPY is stronger for developing countries than for the all-country sample ${ }^{20}$. If country size is not considered as an instrument, the point estimates of IMPY indeed increases for the developing country sample but these are not different from the corresponding estimates for all-country sample reported in Table $7^{21}$.

\footnotetext{
${ }^{20} \mathrm{We}$ do not run a separate regression for developed countries since the number of observations is too small (i.e., 24).

${ }^{21}$ These results are not reported to save space.
} 


\section{Concluding Remarks}

Higher knowledge accumulation in the richer countries provides them with a comparative advantage in knowledge-intensive/higher productivity products. Countries that import products from the richer countries where they have a comparative advantage, therefore, derive benefits from the knowledge spillover. The empirical analysis in this paper suggests that what type of intermediate goods and capital equipments a country imports and from where it imports indeed matters for its long-run growth.

Using highly disaggregated trade data for a large number of countries, we construct an index (denoted as IMPY) that measures the productivity level associated with a country's imports of intermediate products and capital equipments. For each country, the IMPY index is computed for intermediate manufactures and capital goods combined $\left(I M P Y_{\text {combined }}\right)$ as well as separately for intermediate manufactures $\left(I M P Y_{\text {inter }}\right)$ and capital goods $\left(I M P Y_{\text {capital }}\right)$.

Though the IMPY indices show the expected positive coefficient in the OLS regression, a major econometric concern, however, is that this variable is potentially endogenous leading to biased estimates. It is likely that IMPY is correlated with omitted variables that are relevant to growth. The method of instrumental variables (IV) can be used to address the problem of endogeneity. We use insights of the literature on search costs of international trade and on gravity models of trade to obtain the instrumental variables estimates of IMPY's impact on growth. Our instruments are related to the geographic characteristics of the countries, which are not affected by the economic growth rates or by the factors (other than trade) that influence economic growth rates.

The IV estimates show that a higher initial value of the IMPY index (for the year 1995) leads to a faster growth rate of income per capita in the subsequent years (during 1995$2005)$ and vice versa. The point estimates of $I M P Y_{\text {capital }}$ are always larger than that of $I M P Y_{\text {inter }}$, which is expected as capital goods embody higher levels knowledge. Overall, the results imply that a $10 \%$ increase in IMPY increases growth by about 1.3 to1.9 
percentage points, which is quite large. Thus, international trade in capital equipments and intermediate products plays an important role as a transmission channel for knowledge spillovers across the countries.

Formation of different institutional arrangements that can facilitate the sourcing of products from the "right sources" through a process of the global scanning of trading opportunities ought to be encouraged. In general, countries may reap rich dividends by reducing the information barriers and search costs in international trade. 
Table 6: Cross-Country Growth Regressions, IV Estimation

(Dependant Variable: growth rate of GDP per capita (PPP) over: 1995-2005)

\begin{tabular}{|c|c|c|c|c|c|c|}
\hline & (1) & (2) & (3) & (4) & (5) & (6) \\
\hline log initial per capita income & $\begin{array}{l}-0.056 \\
(0.014) * * *\end{array}$ & $\begin{array}{l}-0.043 \\
(0.013) * * *\end{array}$ & $\begin{array}{l}-0.053 \\
(0.014) * * *\end{array}$ & $\begin{array}{l}-0.042 \\
(0.013) * * *\end{array}$ & $\begin{array}{l}-0.060 \\
(0.013) * * *\end{array}$ & $\begin{array}{l}-0.048 \\
(0.013) * * *\end{array}$ \\
\hline log human capital & $\begin{array}{l}0.034 \\
(0.013) * * *\end{array}$ & $\begin{array}{l}0.009 \\
(0.012)\end{array}$ & $\begin{array}{l}0.034 \\
(0.013) * * *\end{array}$ & $\begin{array}{l}0.007 \\
(0.013)\end{array}$ & $\begin{array}{l}0.035 \\
(0.013) * * *\end{array}$ & $\begin{array}{l}0.017 \\
(0.013)\end{array}$ \\
\hline Rule of law index & $\begin{array}{l}0.011 \\
(0.004) * * *\end{array}$ & $\begin{array}{l}0.011 \\
(0.003) * * *\end{array}$ & $\begin{array}{l}0.011 \\
(0.004) * * *\end{array}$ & $\begin{array}{l}0.011 \\
(0.004)^{* * *}\end{array}$ & $\begin{array}{l}0.011 \\
(0.004) * * *\end{array}$ & $\begin{array}{l}0.010 \\
(0.003) * * *\end{array}$ \\
\hline log trade/GDP & $\begin{array}{l}0.031 \\
(0.009) * * *\end{array}$ & $\begin{array}{l}0.028 \\
(0.009) * * *\end{array}$ & $\begin{array}{l}0.031 \\
(0.010) * * *\end{array}$ & $\begin{array}{l}0.031 \\
(0.010) * * *\end{array}$ & $\begin{array}{l}0.021 \\
(0.007) * * *\end{array}$ & $\begin{array}{l}0.015 \\
(0.007) * *\end{array}$ \\
\hline $\log$ initial $I M P Y_{\text {combined }}$ & $\begin{array}{l}\text { 0.098 } \\
(0.041)^{* *}\end{array}$ & $\begin{array}{l}\mathbf{0 . 1 2 7} \\
(0.040) * * *\end{array}$ & - & - & - & - \\
\hline $\log$ initial $I M P Y_{\text {inter }}$ & - & - & $\begin{array}{l}\text { 0.078 } \\
(\mathbf{0 . 0 3 7 ) * *}\end{array}$ & $\begin{array}{l}\mathbf{0 . 1 1 4} \\
(\mathbf{0 . 0 3 9}) * * *\end{array}$ & - & - \\
\hline $\log$ initial $I M P Y_{\text {capital }}$ & - & - & - & - & $\begin{array}{l}\mathbf{0 . 1 5 9} \\
(\mathbf{0 . 0 5 4}) * * *\end{array}$ & $\begin{array}{l}\mathbf{0 . 1 7 3} \\
(\mathbf{0 . 0 5 2}) * * *\end{array}$ \\
\hline FSU Dummy & - & $\begin{array}{l}0.044 \\
(0.009) * * *\end{array}$ & - & $\begin{array}{l}0.048 \\
(0.010)^{* * *}\end{array}$ & - & $\begin{array}{l}0.032 \\
(0.010) * * *\end{array}$ \\
\hline Constant & $\begin{array}{l}-0.350 \\
(0.167)^{* *}\end{array}$ & $\begin{array}{l}-0.490 \\
(0.165) * * *\end{array}$ & $\begin{array}{l}-0.269 \\
(0.156)^{*}\end{array}$ & $\begin{array}{l}-0.436 \\
(0.162)^{* * *}\end{array}$ & $\begin{array}{l}-0.597 \\
(0.216)^{* * *}\end{array}$ & $\begin{array}{l}-0.664 \\
(0.207) * * *\end{array}$ \\
\hline $\begin{array}{l}\text { First-stage } \mathrm{F} \text { on excluded } \\
\text { instruments }\end{array}$ & 22.63 & 22.63 & 19.24 & 19.24 & 16.65 & 16.65 \\
\hline Hansen J-statistic ( $p$-value) & 0.04 & 0.50 & 0.01 & 0.22 & 0.37 & 0.75 \\
\hline Observations & 90 & 90 & 90 & 90 & 90 & 90 \\
\hline
\end{tabular}

Robust standard errors are in parentheses.

* Significant at $10 \%$ level; ** Significant at 5\% level; *** Significant at $1 \%$ level 
Table 7: Cross-Country Growth Regressions, IV Estimation

(Dependant Variable: growth rate of GDP per capita (PPP) over: 1995-2005)

\begin{tabular}{|c|c|c|c|c|c|c|}
\hline & (1) & (2) & (3) & (4) & (5) & (6) \\
\hline log initial per capita income & $\begin{array}{l}-0.067 \\
(0.018)^{* * *}\end{array}$ & $\begin{array}{l}-0.048 \\
(0.014)^{* * *}\end{array}$ & $\begin{array}{l}-0.061 \\
(0.017) * * *\end{array}$ & $\begin{array}{l}-0.045 \\
(0.014) * * *\end{array}$ & $\begin{array}{l}-0.076 \\
(0.021) * * *\end{array}$ & $\begin{array}{l}-0.056 \\
(0.017) * * *\end{array}$ \\
\hline log human capital & $\begin{array}{l}0.032 \\
(0.017)^{* *}\end{array}$ & $\begin{array}{l}0.006 \\
(0.015)\end{array}$ & $\begin{array}{l}0.033 \\
(0.016) * *\end{array}$ & $\begin{array}{l}0.005 \\
(0.016)\end{array}$ & $\begin{array}{l}0.034 \\
(0.019)^{*}\end{array}$ & $\begin{array}{l}0.015 \\
(0.015)\end{array}$ \\
\hline Rule of law index & $\begin{array}{l}0.012 \\
(0.004) * * *\end{array}$ & $\begin{array}{l}0.011 \\
(0.004) * * *\end{array}$ & $\begin{array}{l}0.012 \\
(0.004) * * *\end{array}$ & $\begin{array}{l}0.011 \\
(0.004) * * *\end{array}$ & $\begin{array}{l}0.011 \\
(0.004) * * *\end{array}$ & $\begin{array}{l}0.010 \\
(0.004) * * *\end{array}$ \\
\hline $\log$ trade/GDP & $\begin{array}{l}0.041 \\
(0.015) * * *\end{array}$ & $\begin{array}{l}0.033 \\
(0.012)^{* * * *}\end{array}$ & $\begin{array}{l}0.040 \\
(0.016) * * *\end{array}$ & $\begin{array}{l}0.035 \\
(0.013) * * *\end{array}$ & $\begin{array}{l}0.026 \\
(0.010) * * *\end{array}$ & $\begin{array}{l}0.018 \\
(0.008)^{* *}\end{array}$ \\
\hline $\log$ initial $I M P Y_{\text {combined }}$ & $\begin{array}{l}0.152 \\
(0.067)^{* *}\end{array}$ & $\begin{array}{l}0.156 \\
(0.055) * * *\end{array}$ & - & - & - & - \\
\hline $\log$ initial $I M P Y_{\text {inter }}$ & - & - & $\begin{array}{l}0.112 \\
(0.057)^{* *}\end{array}$ & $\begin{array}{l}\mathbf{0 . 1 3 4} \\
(\mathbf{0 . 0 5 2}) * * *\end{array}$ & - & - \\
\hline $\log$ initial $I M P Y_{\text {capital }}$ & - & - & - & - & $\begin{array}{l}0.261 \\
(0.102) * * *\end{array}$ & $\begin{array}{l}\mathbf{0 . 2 2 8} \\
(\mathbf{0 . 0 8 3}) * * *\end{array}$ \\
\hline FSU Dummy & - & $\begin{array}{l}0.048 \\
(0.010) * * *\end{array}$ & - & $\begin{array}{l}0.052 \\
(0.012) * * *\end{array}$ & - & $\begin{array}{l}0.034 \\
(0.013) * * *\end{array}$ \\
\hline Constant & $\begin{array}{l}-0.575 \\
(0.282)^{* *}\end{array}$ & $\begin{array}{l}-0.613 \\
(0.233) * * *\end{array}$ & $\begin{array}{l}-0.413 \\
(0.242)^{*}\end{array}$ & $\begin{array}{l}-0.520 \\
(0.222)^{* *}\end{array}$ & $\begin{array}{l}-1.019 \\
(0.415)^{* * *}\end{array}$ & $\begin{array}{l}-0.894 \\
(0.339) * * *\end{array}$ \\
\hline $\begin{array}{l}\text { First-stage } \mathrm{F} \text { on excluded } \\
\text { instruments }\end{array}$ & 17.14 & 17.14 & 12.38 & 12.38 & 18.08 & 18.08 \\
\hline Hansen J-statistic ( $p$-value) & 0.03 & 0.42 & 0.01 & 0.14 & 0.93 & 0.96 \\
\hline Observations & 90 & 90 & 90 & 90 & 90 & 90 \\
\hline
\end{tabular}

Robust standard errors are in parentheses.

* Significant at $10 \%$ level; ** Significant at $5 \%$ level; *** Significant at $1 \%$ level 
Table 8: Cross-Country Growth Regressions, Developing Country Sample, IV Estimation (Dependant Variable: growth rate of GDP per capita (PPP) over: 1995-2005

\begin{tabular}{|c|c|c|c|}
\hline & $(1)$ & (2) & (3) \\
\hline log initial per capita income & $\begin{array}{l}-0.040 \\
(0.014) * * *\end{array}$ & $\begin{array}{l}-0.038 \\
(0.015) * * *\end{array}$ & $\begin{array}{l}-0.045 \\
(0.014) * * *\end{array}$ \\
\hline log human capital & $\begin{array}{l}0.004 \\
(0.014)\end{array}$ & $\begin{array}{l}0.002 \\
(0.015)\end{array}$ & $\begin{array}{l}0.016 \\
(0.014)\end{array}$ \\
\hline Rule of law index & $\begin{array}{l}0.015 \\
(0.005) * * *\end{array}$ & $\begin{array}{l}0.015 \\
(0.005) * * *\end{array}$ & $\begin{array}{l}0.015 \\
(0.005)^{* * *}\end{array}$ \\
\hline log trade/GDP & $\begin{array}{l}0.018 \\
(0.013)\end{array}$ & $\begin{array}{l}0.021 \\
(0.014)\end{array}$ & $\begin{array}{l}-0.001 \\
(0.012)\end{array}$ \\
\hline $\log$ initial $I M P Y_{\text {combined }}$ & $\begin{array}{l}\mathbf{0 . 1 3 0} \\
(\mathbf{0 . 0 4 1}) * * *\end{array}$ & - & - \\
\hline $\log$ initial $I M P Y_{\text {inter }}$ & - & $\begin{array}{l}\mathbf{0 . 1 1 5} \\
(\mathbf{0 . 0 4 0} * * *\end{array}$ & - \\
\hline $\log$ initial $I M P Y_{\text {capital }}$ & - & - & $\begin{array}{l}\mathbf{0 . 1 6 4} \\
(0.046) * * *\end{array}$ \\
\hline FSU Dummy & $\begin{array}{l}0.047 \\
(0.009)\end{array}$ & $\begin{array}{l}0.050 \\
(0.010) * * *\end{array}$ & $\begin{array}{l}0.034 \\
(0.009) * * *\end{array}$ \\
\hline Constant & $\begin{array}{l}-0.486 \\
(0.172) * * *\end{array}$ & $\begin{array}{l}-0.427 \\
(0.171)^{* * *}\end{array}$ & $\begin{array}{l}-0.603 \\
(0.184)^{* * * *}\end{array}$ \\
\hline $\begin{array}{l}\text { First-stage F on excluded } \\
\text { instruments }\end{array}$ & 16.27 & 13.85 & 9.84 \\
\hline Hansen J-statistic ( $p$-value) & 0.11 & 0.03 & 0.56 \\
\hline Observations & 66 & 66 & 66 \\
\hline
\end{tabular}

Robust standard errors are in parentheses.

* Significant at 10\% level; ** Significant at 5\% level; *** Significant at $1 \%$ level 


\section{References}

Acemoglu, Daron and Fabrizio Zillibotti (1999) "Information Accumulation in Development", Journal of Economic Growth, 4(1), 5-38.

Aghion, Philippe and Peter Howitt (1992) "A Model of Growth Through Creative Destruction", Econometrica, 60(2), 323-351.

Balassa (1965) "Trade liberalization and revealed comparative advantage", Manchester School of Economics and Social Studies, 33(2), 99-123.

Besedes, Tibor and Thomas Prusa (2006), "Ins, Outs, and the Duration of Trade," Canadian Journal of Economics, 39(1), 266-295.

Broda, Christian, Joshua Greenfield and David Weinstein, (2006) "From Groundnuts to Globalization: A Structural Estimate of Trade and Growth", NBER working paper No 12512, Cambridge MA.

Chuang, Yih-chyi (1998) "Learning by Doing, the Technology Gap and Growth", International Economic Review, 39(3), 697-721.

Coe, David T and Elhanan Helpman (1995) "International R\&D Spillovers" European Economic Review, 39(5), 859-87

Coe, David T, Elhanan Helpman and Alexander W Hoffmaister (1997) "North-South R\&D Spillovers", The Economic Journal, 107 (439), 134-49.

Falvey, R, E and H. Kierzkowski (1987), "Product Quality, Intra-Industry Trade and (Im)Perfect Competition". In H. Kierzkowski (Ed.), Protection and Competition in International Trade: Essays in Honor of W.M. Corden, Oxford, Basil Blackwell.

Feenstra, Robert C (2004) Advanced International Trade: Theory and Evidence, Princeton University Press, Princeton and Oxford

Fidrmuc, Jarko and Jan Fidrmuc (2003), "Disintegration and Trade”, Review of International Economics, 11 (5), 811-829.

Flam, Harry and Elhanan Helpman (1987) "Vertical Product Differentiation and North-South Trade", American Economic Review, 77 (5), 810-822.

Frankel Jeffrey A and David Romer (1999), "Does Trade Cause Growth" American Economic Review, 89(3), 379-99.

Goh, Ai-Ting and Jacques Olivier (2002), "Learning by Doing, Trade in Capital Goods and Growth", Journal of International Economics, 56 (2), 411-444.

Grossman, Gene M and Elhanan Helpman (1991), Innovation and Growth in the Global Economy, The MIT Press, Cambridge MA. 
Hausmann, Ricardo and Dani Rodrik (2003) "Economic Development as Self Discovery", Journal of Development Economics, 72(2), 603-633.

Hausmann, Ricardo and Bailey Klinger (2006), "Structural Transformation and Patterns of Comparative Advantage in the Product Space", Working Paper No.128, Centre for International Development, Harvard University

Hausman, Ricardo, Jason Hwang and Dani Rodrik (2007) "What you Export Matters", Journal of Economic Growth, 12 (1), 1-25.

Keller, Wolfgang (2000) "Do Trade Patterns and Technology Flows Affect Productivity Growth", The World Bank Economic Review, 14 (1), 17-47.

Keller, Wolfgang (2004) "International Technology Diffusion", Journal of Economic Literature, 42 (3), 752-82.

Iradian, Garbis (2007) "Rapid Growth in Transition Economies: Growth-Accounting Approach”, IMF Working Paper No. 07/164.

Leamer, Edward E. and James Levinsohn (1995), "International Trade Theory: The Evidence,", in G. M. Grossman and K. Rogoff (ed.), Handbook of International Economics, edition 1, volume 3, chapter 26, pages 1339-1394, Elsevier.

Murphy Kevin M and Andrei Shleifer (1997) "Quality and Trade.", Journal of Development Economics, 53(1), pp. 1-15.

Rauch, James E (1999)"Networks versus Markets in International Trade", Journal of International Economics, 48(1), 7-35.

Rauch, James E (2001) "Business and Social Networks in International Trade" Journal of Economic Literature, 39 (4), 1177-1203

Romer, Paul M (1987), "Growth Based on Increasing Returns Due to Specialization", American Economic Review, 77(2), pp 56-62.

Rose, Andrew K (2006) “Size Really Doesn't Matter: In Search of a National Scale Effect”, NBER Working Paper No. 12191.

Schott, Peter (2004), “Across-product versus Within-product Specialization in International Trade", Quarterly Journal of Economics, 119(2), 647-678.

Stokey, Nancy L (1991) "Human Capital, Product Quality, and Growth" The Quarterly Journal of Economics, 106 (2), pp. 587-616

Wooldrige, Jeffrey (2003), Introductory Econometrics: A Modern Approach, South Western/Thomson Learning, Ohio.

$\mathrm{Xu}$, Bin and Jianmao Wang (1999), "Capital Goods Trade and R\&D Spillovers in the OECD”, Canadian Journal o Economics, 32 (5), 1258-1274. 


\section{Appendix}

\section{Data Sources}

\begin{tabular}{|l|l|}
\hline Variable & Data Source \\
\hline $\begin{array}{l}\text { Export and import values (US\$) } \\
\text { at the 6-digit level of HS }\end{array}$ & $\begin{array}{l}\text { United Nations' COMTRADE database accessed through } \\
\text { the World Integrated Trade Statistics (WITS) software. }\end{array}$ \\
\hline $\begin{array}{l}\text { Real per capita income (PPP- } \\
\text { adjusted and at market exchange } \\
\text { rates) }\end{array}$ & World Development Indicators, World Bank \\
\hline $\begin{array}{l}\text { Secondary School Enrollment } \\
\text { Ratio }\end{array}$ & $\begin{array}{l}\text { Easterly, William R (2001) "Global Development Network } \\
\text { Growth Database" } \\
\text { (http://go.worldbank.org/ZSQKYFU6J0) } \\
\text { Development Indicators, World Bank. }\end{array}$ \\
\hline Rule of law index & $\begin{array}{l}\text { Daniel Kaufmann, Aart Kraay and Massimo Mastruzzi } \\
\text { (2007), "Governance Matters VI: Aggregate and Individual } \\
\text { Governance Indicators" World Bank Policy Research } \\
\text { Working Paper 4280 (www.govindicators.org) }\end{array}$ \\
\hline Trade/GDP ratio & World Development Indicators, World Bank \\
\hline Population & World Development Indicators, World Bank \\
\hline Landlock and Island Status & $\begin{array}{l}\text { Easterly, William R (2001) "Global Development Network } \\
\text { Growth Database" and the "World Factbook", CIA website } \\
\text { (https://www.cia.gov/) }\end{array}$ \\
\hline Distance & $\begin{array}{l}\text { Estimated using data downloaded from the CEPII website } \\
\text { (http://www.cepii.fr/anglaisgraph/bdd/distances.htm) }\end{array}$ \\
\hline
\end{tabular}

Notes:

${ }^{a}$ Because data are not available for 1995, the data for the closest year (before or after 1995) have been used for a few countries.

b These data are available for 1996, 1998, 2000, and annually for 2002-2006. We used the simple average for the period 1996-2005.

${ }^{\mathrm{c}}$ We used the simple average for the period 1995-2005.

${ }^{\mathrm{d}}$ Data for the year 1995 is used.

${ }^{\mathrm{e}}$ Great circle distance between the important cities of countries are used. 